\title{
Job Retention Factors, Perceived Career Mobility and Organisational Commitment in the South African Financial Sector
}

\author{
Tanzia F. Joāo and Melinde Coetzee \\ University of South Africa
}

\begin{abstract}
This study explores job retention factors, perceived career mobility and organisational commitment among early career employees. Participants were professional auditors, accountants and financial staff $(N=82)$ in the finance industry in South Africa (57\% = females, $70 \%$ White, age range between 17 and 29 years). They completed a career mobility survey and an organisational commitment measure. Data were analysed to identify key retention factors and relate employee demographics to their perceptions of career mobility and organisational commitment. The results suggest that older employees perceived the cost of leaving to influence their career mobility and organisational commitment. Younger Black employees regarded career advancement important for their career mobility and organisational commitment. Talent retention strategies for professional staff members in the financial sector should take into account their need for intra-organisational career mobility, work-life balance, knowledge and skills utilisation and competitive compensation.
\end{abstract}

- Keywords: career mobility; financial sector; organisational commitment; retention, demographics, early career.

\section{Influence of Demographics}

Organisations are increasingly recognising the value of attracting and retaining staff from all demographic groups in order to improve workforce performance and thus promote their competitive position (Torrington, Hall, Taylor, \& Atkinson, 2009). Demographics tend to reflect a surface-level diversity that points to differences in easily perceived characteristics (e.g., age, gender and race). Deep-level diversity characteristics reflect what people individually think and feel about their organisations, jobs and careers. Being characteristics that people commonly share, they are recognised as important factors in shaping people's individual mindsets about their organisational lives. Deep-level diversity characteristics become progressively more important for determining similarity within groups as people get to know one another better (Robbins \& Judge, 2009).

Perceived career mobility opportunities and organisational commitment influence job retention (Döckel, Basson, \& Coetzee, 2006; Feldman \& Ng, 2007; Lo Presti, 2009; Mallol, Holtom, \& Lee, 2007). However, aspects of intra and intercareer mobility and their influence on job retention in a developing world context are in need of study. Perceived career mobility refers to an individual's perception of the opportunity for intra-organisational and interorganisational career mobility.

Intra-organisational career mobility refers to job changes that include substantial changes in work responsibilities, hierarchical level or titles within an organisation (Feldman \& Ng, 2007). It also refers to occupational change, which includes transitions that require fundamentally new skills, routines and work environments, along with new training, education or vocational preparation within an organisation. On the other hand, interorganisational change refers to movement between organisations (Feldman \& Ng, 2007). Voluntary turnover, with a focus on interorganisational career mobility, has been studied by analysing job-hopping by employees (Fallic, Fleischman,

ADDRESS FOR CORRESPONDENCE: Professor Melinde Coetzee, Department of Industrial \& Organisational Psychology, University of South Africa, P.O. Box 392 Pretoria 003. E-mail: coetzm1@unisa.ac.za 
\& Rebitzer, 2006; Khatri, Fern, \& Budhwar, 2001; Vallabh \& Donald, 2001). Intra-organisational career mobility has commonly been studied by focusing on the need for advancement opportunities in the understanding of career mobility (Brown, 1998) and retention (Sutherland \& Jordaan, 2004).

\section{Career Mobility Opportunities}

The satisfaction of specific career mobility preferences through the provision of career mobility opportunities may assist in embedding employees (Ng, Sorensen, Eby, \& Feldman, 2007) with the aim of talent retention. The provision of career development opportunities by organisations provides the impression that the organisation values the employees (Foong-ming, 2008). Lesabe and Nkosi (2007) assert that employees possess the need to progress and grow, and become frustrated when they perceive their path to progress to be blocked. Kochanski and Ledford (2001) identified that career opportunities yielded more significant predictors of retention than any other type of reward, followed by training opportunities and an employee's relationship with his or her supervisor.

Major influences include macroeconomic conditions, as the greater the growth of an economy the more jobs are available. From an occupational perspective, major labour market occupational factors include industry growth, human capital investments and the rigidity and permeability of occupational mobility structures. The more permeable occupational boundaries are and the greater industry growth, the easier it would be for employees to move between occupations. Moreover, employee perceptions of these reduced boundaries may increase their confidence in their ability to successfully move between occupations (Feldman \& Ng, 2007).

\section{Organisational Commitment}

Organisational commitment refers to an attitude in terms of a stable mindset to the organisation (Meyer \& Allen, 1997). Meyer and Allen's (1991) three-component model of organisational commitment (i.e., affective, continuance and normative commitment) is of relevance to this research due to the wealth of support for, and research on, these authors' approach to organisational commitment.

Affective commitment arises from a sense of emotional attachment, continuance commitment is rooted in a sense of economic necessity and normative commitment occurs out of a sense of moral obligation to remain (Coetzee \& Roythorne-Jacobs, 2012). Employees experiencing affective commitment remain because they desire to do so, those experiencing continuance commitment remain because they need to and those experiencing normative commitment remain due to a sense of obligation to the organisation (Meyer \& Allen, 1991). Meyer and Herscovitch (2001) propose that affective commitment is developed through any variables, personal or situational, that contribute to the likelihood that an individual will become intrinsically motivated to a course of action and recognise the value of and/or develop identity from association with an entity or the pursuit of an action. These variables may include supervisor support and recognition (Meyer \& Allen, 1997; Rhoades \& Eisenberger, 2002; Wayne, Shore, Bommer, \& Tetrick, 2002); the perception of being treated fairly to enhance an employee's sense of personal importance and competence (Meyer \& Allen, 1997); age, whereby older employees, or those with longer tenure, tend to be more committed (Levy, 2010); and gender (Mguqulwa, 2008).

According to Spector (2000), affective commitment occurs as a result of job conditions and met expectations, while continuance commitment occurs as a product of benefits accumulated from working for the organisation and by a lack of alternative jobs. The latter is of particular interest to this study. Meyer and Allen (1991) propose that continuance commitment may develop as a result of the perception of a lack of alternatives. Studies regarding the relationship between gender and organisational commitment have yielded inconsistent results (Martin, 2007). Meyer and Allen (1997) hypothesise that early socialisation processes may have an impact on employee normative commitment, as there is indirect evidence that suggests that employees with a need to fulfil their obligations to others are more likely to be normatively committed.

Kondratuk, Hausdorf, Korabik and Rosin (2004) propose that the relationship between career mobility and organisational commitment differs for inter- and intraorganisational mobility and is dependent on time (before or after the move). Individuals may have a high mobility history, but may not perceive current mobility opportunities due to situational factors and therefore it is important to assess an individual's perception of his or her current career mobility opportunities and the relationship of this perception with organisational commitment. These findings point to the importance of understanding how diverse groups of staff differ with regard to their perceived career mobility and organisational commitment.

\section{The South African Context}

Due to the affirmative action and employment equity policies implemented in the South African context, skilled Black professionals are in short supply and high demand (Vallabh \& Donald, 2001). In addition, organisations experience difficulty in the retention of certain accounting and auditing professionals due to the high demand for these professionals (Pato \& Spira, 2008). Employment equity legislation has enhanced career mobility for historically disadvantaged groups. Various studies have explored the relationship between external career mobility and, more specifically, intent to leave and race (Martin \& Roodt, 2007; Vallabh \& Donald, 2001). White South African employees experienced greater levels of satisfaction for several job facets, including promotional 
opportunities, which is a key aspect of perceived intraorganisational career mobility (Lumley, 2009).

Likewise, Mncwango and Winnaar (2009) reported that, after job security, South African employees value good advancement opportunities. The aforementioned views highlight the need for the provision of organisational career mobility opportunities, such as advancement opportunities.

\section{Goals of the Study}

The objective of the study was to explore job retention factors and the relationship between perceived career mobility and organisational commitment among professionally qualified staff in the South African financial sector. There also seems to be a paucity of research about how people from diverse demographic backgrounds (i.e., age and race) in the South African financial sector differ in terms of their perceptions of the availability of career mobility opportunities and organisational commitment. The specific research questions were:

- What are the retention factors that professionals in the South African financial sector regard as important for keeping them from leaving their companies?

- Is there a statistically significant relationship between perceived career mobility and organisational commitment?

- Do individuals younger and older than 30 years, and Blacks and Whites differ significantly regarding their perceived career mobility and organisational commitment?

\section{Method}

\section{Participants}

Of a total population of 280,000 professionals in the financial management, accounting and auditing field in South Africa, a nonprobability convenience sample of 250 $(N=250)$ participants were invited to participate in the research study. A final sample of 82 completed questionnaires was usable, thus yielding a response rate of $33 \%$. The sample $(n=82)$ comprised individuals mostly aged between 17 and 29 years (66\%), and individuals 30 years and older (34\%). The sample was represented by $43 \%$ males and 57\% females, indicating that the sample was fairly evenly split between gender groups. Seventy-nine per cent of the sample had only worked for their employing organisation for five years or less. The majority of the sample was White (70\%), with few Black (30\%), (18\% African, $6 \%$ coloured and $6 \%$ Indian) participants. Most of the participants were highly qualified, with a degree or higher $(87 \%)$. High qualification levels generally are expected due to the nature of the work conducted by the participating sample.

\section{Measuring Instruments}

Participants completed a perceived career mobility scale that was designed for this study. The scale consists of 13 items divided into two scales: perceived interorganisational career mobility opportunities (4 items) and perceived intra-organisational career mobility opportunities (9 items). The two scales also include additional items relating to reasons people think that it is easy for them to find a job within another organisation and an item relating to 17 factors that would keep individuals from leaving an organisation. Questions are answered on a 5-point rating scale (strongly disagree to strongly agree). In terms of the present study, acceptable internal consistency reliabilities were yielded for the two subscales: perceived interorganisational career mobility (.85) and perceived intra-organisational career mobility (.64).

The Organisational Commitment Scale (OCS; Meyer \& Allen, 1997) measures total commitment and comprises three subscales: affective commitment ( 6 items), continuance commitment (6 items) and normative commitment (6 items) on a 5-point Likert scale. Döckel (2003) reported acceptable internal consistency reliability estimates (Cronbach's alphas) for affective commitment (.82), continuance commitment (.74) and normative commitment (.83). High internal consistency reliabilities of .86 (total commitment), .74 (affective commitment), .86 (continuance commitment) and .89 (normative commitment) were yielded in this study.

\section{Research Procedure}

Permission for the study was granted by the participating organisations and the South African Institute for Chartered Accountants (SAICA). Participants were approached directly and asked to participate. This was done with the use of SAICA's list of contact information for all members, which is available for use by the public. Only auditors employed by an organisation were included. In addition, the management of five South African organisations were informed regarding this study, the management of these organisations then informed relevant employees about the study. Participation was voluntary. In terms of ethics, clearance to conduct the research was obtained from the participating organisations and SAICA. Confidentiality and privacy were explained, as well as the purpose of the study and the feedback to be received. Written informed consent was obtained as the participants completed an informed consent form, and it was indicated to the participants that the completion and return of the questionnaire and consent form signified that they granted permission for their questionnaire to be used for research purposes.

\section{Statistical Analyses}

SPSS version 17 (2008) was used to analyse the quantitative data of the empirical study by performing the statistical data analyses. Descriptive statistics were used to 
analyse the reasons people think that it is easy for them to find a job within another organisation, and the 16 factors that would keep individuals from leaving an organisation. Correlational statistics were performed to assess the direction and strength between participants' perceived career mobility and organisational commitment. To test for statistically significant mean differences between the age, gender and race groups regarding the participants' perceived career mobility and organisational commitment $t$ tests and ANOVAs were performed. A cut-off point of $p \leq .05$ was set to interpret the significance of the findings.

\section{Results}

\section{Descriptive Statistics: Perceived Career Mobility and Retention Factors}

As summarised in Table 1, the participants obtained the highest mean scores on the perceived interorganisational career mobility variable $(M=3.24 ; S D=0.88)$. The perceived intra-organisational career mobility mean scores were moderately high $(M=3.16 ; S D=0.80)$. Table 2 shows that the two highest rated reasons for why the participants think it would be easy for them to find a job with another organisation are due to their skills and knowledge and due to the high demand for employees within their field of work. Table 3 shows that the seven highest rated factors for keeping the participants from leaving their companies relate to five core retention themes, namely (1) work/life balance, (2) opportunities to use and apply their knowledge and skills in the company, (3) salary and benefits (compensation), (4) opportunities for career growth and development and (5) challenging work.

\section{Descriptive Statistics: Organisational Commitment}

As summarised in Table 1, the participants obtained the highest mean scores on the affective commitment variable $(M=3.18 ; S D=0.94)$ and the lowest mean score on the continuance commitment variable $(M=2.98 ; S D=$ $0.81)$. The participants' overall level of organisational commitment obtained moderately high scores $(M=$ $3.06 ; S D=0.71)$.

\section{TABLE 1}

Descriptive Statistics: Means, Standard Deviations and Cronbach's Alpha Coefficients ( $\mathrm{N}=82$ )

\begin{tabular}{lccc}
\hline Scales & Mean & SD & $\begin{array}{c}\text { Cronbach's } \\
\text { Alpha } \\
\text { coefficients }\end{array}$ \\
\hline Total perceived career mobility & 2.89 & 0.65 & .83 \\
Perceived interorganisational career mobility & 3.24 & 0.88 & .85 \\
Perceived intra-organisational career mobility & 3.16 & 0.80 & .64 \\
Total commitment & 3.06 & 0.71 & .86 \\
Affective commitment & 3.18 & 0.94 & .74 \\
Continuance commitment & 2.98 & 0.81 & .86 \\
Normative commitment & 3.01 & 0.91 & .89
\end{tabular}

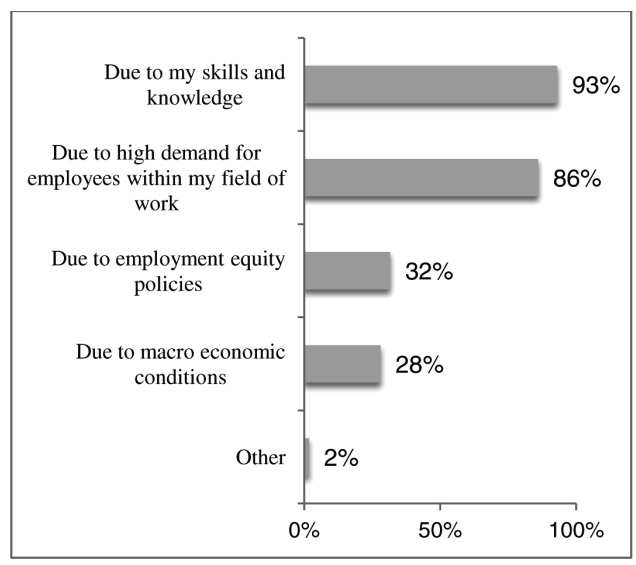

TABLE 2

Reasons Participants Think That It Is Easy for Them to Find a Job Within Another Organisation

\section{Correlational Statistics}

Table 4 shows that the organisational commitment variables correlated significantly with the following variables: perceived career mobility variable, with the exception of the total perceived career mobility, continuance commitment, perceived interorganisational career mobility, total, affective and normative commitment, perceived intraorganisational career mobility and continuance commitment. The significant correlations between the perceived career mobility and organisational commitment variables were all positive, with the exception of the relationship between perceived interorganisational career mobility and continuance commitment. The correlations vary from $r=-.28$ (small practical effect size; $p \leq .01$ ) to $r=.48$ (large practical effect size; $p \leq .001$ ).

\section{Inferential Statistics: Tests for Significant Mean Differences}

Age. Table 5 shows that the participants younger than 30 years obtained statistically significant higher mean scores than their older counterparts on the perceived interorganisational career mobility variable $(M=3.41$ vs. $M=2.93$; $p$ $\leq .05)$. The participants 30 years and older scored significantly higher than the younger participants on the total organisational commitment $(M=3.32$ vs. $M=2.92 ; p \leq$ $.05)$, affective commitment $(M=3.52$ vs. $M=3.00 ; p \leq$ $.05)$ and continuance commitment $(M=3.27$ vs. $M=$ 2.83; $p \leq .05$ ) variables.

Gender. No statistically significant differences were observed between the mean scores of the male and female participants on the perceived career mobility and organisational commitment variables.

Race. Table 5 indicates that the Black participants scored significantly higher than their White counterparts on perceived interorganisational career mobility $(M=3.80$ vs. $M$ 
TABLE 3

Factors That Would Keep Participants from Leaving Their Companies

\begin{tabular}{|c|c|c|c|}
\hline Retention factors & Ranked order & Mean & SD \\
\hline Salary & 5 & 4.26 & 0.97 \\
\hline Benefits provided by the organisation & 4 & 4.27 & 0.80 \\
\hline The leadership of the organisation & 8 & 4.20 & 0.91 \\
\hline The organisation provides diversity programs & 17 & 3.41 & 1.17 \\
\hline Trust within the organisation & 9 & 4.18 & 0.89 \\
\hline Supervisor recognition of the work which I have done. & 10 & 4.13 & 0.83 \\
\hline An opportunity to utilise my knowledge and skills & 2 & 4.38 & 0.78 \\
\hline The organisation invests in skill development training & 11 & 4.12 & 0.89 \\
\hline Social friendships within the organisation & 16 & 3.68 & 0.99 \\
\hline Ability to balance my work and family life & 1 & 4.39 & 0.78 \\
\hline Supervisor feedback & 14 & 3.96 & 0.87 \\
\hline Career opportunities within the organisation & 12 & 4.00 & 0.98 \\
\hline The organisation has relevant resources & 13 & 3.98 & 0.86 \\
\hline Challenging work & 7 & 4.21 & 0.84 \\
\hline Employees within the organisation are promoted & 15 & 3.90 & 1.01 \\
\hline Opportunities for career growth and development & 6 & 4.23 & 0.89 \\
\hline Opportunities to apply my knowledge & 3 & 4.32 & 0.77 \\
\hline
\end{tabular}

$=3.08 ; p \leq .01)$. No statistically significant differences were observed between the mean scores of the White and Black participants on the organisational commitment variables.

\section{Discussion}

Perceived career mobility was influenced by job opportunities in other organisations or high demand for employees within their sector. These results are not surprising, as a recent report by SAICA (South African Institute of Chartered Accountants, 2008) found a shortage of financial staff, accountants and auditors in the South African work context. Research by Kochanski and Ledford (2001) has shown that skills shortages, and hence a high demand for employees, results in greater career mobility opportunities. The higher scores on perceived interorganisational career mobility opportunities are interesting in the light of the lower mean scores for normative and continuance commitment. Individuals perceiving that they have several job opportunities in the job market may not experience the need to be committed to an organisation due to the costs involved in leaving, or because of feeling obligated to stay in the organisation.
The results further revealed that the participants who preferred intra-organisational career mobility opportunities, that is, opportunities to advance or develop within the organisation, appeared to feel emotionally more attached to the organisation. Kondratuk et al. (2004) suggest in this regard that affective commitment increases after a move within or between organisations.

Younger Black employees were relatively more optimistic about their career intra-organisational career mobility. This could be attributed to the employment equity and affirmative action legislation in South African organisations that provide for career mobility opportunities for historically disadvantaged people. On the other hand, older workers were affectively more committed to their organisations seemingly due to the perceived costs of leaving their organisations and having 'cognitively justified' their continuance in an organisation. Several studies have reported a trend whereby older employees tend to report greater organisational commitment (Martin \& Roodt, 2007). The findings are consistent with those of Levy (2010) and D’Manto and Herzfeldt (2008), who found older employees to be more committed. Martin and

\section{TABLE 4}

Correlation Analysis Between Perceived Career Mobility and Organisational Commitment $(\mathrm{N}=82)$

\begin{tabular}{|c|c|c|c|c|}
\hline Organisational commitment & & $\begin{array}{l}\text { Total perceived } \\
\text { career mobility }\end{array}$ & $\begin{array}{l}\text { Perceived interorganisational } \\
\text { career mobility }\end{array}$ & $\begin{array}{l}\text { Perceived intraorganisational } \\
\text { career mobility }\end{array}$ \\
\hline Total & $r$ & $.38^{\star \star \star \star}$ & & $.43^{\star \star \star}$ \\
\hline Affective & $r$ & $.48^{\star \star \star}$ & & $.48^{\star \star \star}$ \\
\hline Continuance & $r$ & & $-.28^{\star \star}$ & \\
\hline Normative & $r$ & $.36^{\star \star \star}$ & & $.41^{\star \star \star}$ \\
\hline
\end{tabular}

Note: ${ }^{* \star} p \leq .001 ;{ }^{\star *} p \leq .01 ;{ }^{\star} p \leq .05$ (two-tailed) 
TABLE 5

Statistically Significant Mean Differences: Age and Race

\begin{tabular}{|c|c|c|c|c|c|c|c|c|}
\hline \multirow{2}{*}{$\begin{array}{l}\text { Biographical variable } \\
\text { Age }\end{array}$} & \multicolumn{2}{|c|}{$\begin{array}{l}\text { Levene's Test for } \\
\text { Equality of } \\
\text { Variances }\end{array}$} & \multicolumn{3}{|c|}{$\begin{array}{l}\quad t \text { test for } \\
\text { Equality of Means }\end{array}$} & \multirow[t]{2}{*}{$\begin{array}{l}\text { Biographical } \\
\text { group }\end{array}$} & \multirow[b]{2}{*}{ Mean } & \multirow[b]{2}{*}{$S D$} \\
\hline & $F$ & Sig. & $t$ & $d f$ & Sig. & & & \\
\hline Perceived interorganisational career mobility & 0.77 & 0.38 & 2.4 & 80 & $.02^{*}$ & $\begin{array}{l}17-29 \text { years } \\
\geq 30 \text { years }\end{array}$ & $\begin{array}{l}3.41 \\
2.93\end{array}$ & $\begin{array}{l}0.81 \\
0.94\end{array}$ \\
\hline Total organisational commitment & 1.06 & 0.31 & -2.49 & 80 & $.02^{*}$ & $\begin{array}{l}17-29 \text { years } \\
\geq 30 \text { years }\end{array}$ & $\begin{array}{l}2.92 \\
3.32\end{array}$ & $\begin{array}{l}0.65 \\
0.76\end{array}$ \\
\hline Affective commitment & 0.12 & 0.73 & -2.43 & 80 & $.02^{*}$ & $\begin{array}{l}17-29 \text { years } \\
\geq 30 \text { years }\end{array}$ & $\begin{array}{c}3 \\
3.52\end{array}$ & $\begin{array}{l}0.87 \\
0.99\end{array}$ \\
\hline Continuance commitment & 0.61 & 0.44 & -2.42 & 80 & $.02^{*}$ & $\begin{array}{l}17-29 \text { years } \\
\geq 30 \text { years }\end{array}$ & $\begin{array}{l}2.83 \\
3.27 \\
\end{array}$ & $\begin{array}{l}0.75 \\
0.85 \\
\end{array}$ \\
\hline \multicolumn{9}{|l|}{ Race } \\
\hline Perceived interorganisational career mobility & 11.79 & 0.001 & -2.9 & 70 & $.01^{\star \star}$ & White & 3.08 & 0.93 \\
\hline $\begin{array}{l}\text { Perceived inter-organisational career mobility } \\
\text { (Equal variances not assumed) }\end{array}$ & & & -4.41 & 52.92 & $.00^{\star \star \star}$ & Black & 3.8 & 0.41 \\
\hline
\end{tabular}

${ }^{\star \star \star} p \leq .001 ;{ }^{* \star} p \leq .01 ;{ }^{*} p \leq .05$ (two-tailed)

Roodt (2007) suggest that the relationship between age and organisational commitment may be supported by the idea that fewer job opportunities, due to an increase in age and specialisation, may result in increased organisational commitment by these employees.

When employees feel positive about the availability of future growth and advancement opportunities within their companies, they tend to feel emotionally more attached to the organisation. Allen, Shore and Griffeth (2003) reported in this regard that perceived organisational support, including growth opportunities, result in employees' perceptions that the organisation cares about them, leading to increased emotional attachment to the organisation. A lack of growth opportunities have been found to negatively influence an individual's attitude towards the organisation, which in turn influences the intention to leave, leading to turnover behaviour (Allen et al., 2003).

Work/life balance, opportunities for career growth and development and using one's skills and knowledge in the company, compensation and challenging work are indicated as some of the most important retention factors for the employees. Döckel, Basson and Coetzee (2006) found the relation between work/life policies and affective commitment to be significant. Employees in the establishment and achievement phases of their careers appear to be emotionally attracted to the organisation most probably because of the work/life benefits available to them. These benefits are generally seen as a general indicator of corporate concern and responsibility. Research by Lumley (2009) indicates that employees who felt positive about the possibility of advancement opportunities within the organisation, and who felt intrinsically motivated by their job tasks, their achievements and opportunities to use their abilities, skills and knowledge (i.e., those who experienced intrinsic job satisfaction), seemed more likely to feel emotionally attached to the organisation. A study by Lesabe and Nkosi (2007) suggest that employees feel motivated to go the extra mile if they knew that they would be financially rewarded, since they regard money as enabling them to afford better things in life. Vallabh and Donald (2001) found pay and career mobility as leading factors in the decision to stay or leave the organisation. Lumley (2009) reported that employees who are satisfied with pay, promotion (advancement), fringe benefits, contingent rewards (recognition and achievement) and the nature of their work, are more likely to feel emotionally attached to and involved with their employing organisation. They are also more likely to feel obliged to remain with the organisation because of social norms (i.e., normatively committed).

\section{Limitations and Recommendations}

The present study was limited to a relatively small sample of participants predominantly in the financial sector. Therefore, the findings cannot be generalised to other economic sectors and occupational contexts. Secondly, given that the sample was predominantly represented by Whites and individuals in the exploration phase of their careers, a more balanced sample would have contributed more meaningful insights regarding the differences between race, gender and age groups. It is recommended that participants from various organisations and occupational contexts and a more demographic diverse group be used in future studies to obtain a more representative sample. Thirdly, longitudinal studies are needed in order to validate the differences observed in this study between the various sociodemographic groups.

\section{Conclusions}

Younger Black employees (especially those in the entry and exploration phases of their careers) tend to experience 
greater interorganisational mobility opportunities and may therefore feel potentially less attached to the organisation. They may need targeted retention strategies when considering that current employment equity and affirmative action legislation have opened up career mobility opportunities for these employees. Moreover, targeted retention strategies for this group of young professionals are also important in the light of the current retention problems experienced by South African organisations (Pato \& Spira, 2008) and the perceived high demand for their skills and knowledge. Talent retention strategies for professional staff members in the financial sector should take into account their need for intra-organisational career mobility, work-life balance, knowledge and skills utilisation and competitive compensation. The findings of the present study contribute valuable new knowledge that may be used to inform retention strategies for young professionals in the South African financial sector.

\section{Author note}

This study formed part of a supervised master's project.

\section{References}

Allen, D.G., Shore, L.M., \& Griffeth, R.W. (2003). The role of perceived organizational support and supportive human resource practices in the turnover process. Journal of Management, 29, 99-118.

Brown, B.L. (1998). Career mobility: A choice or necessity. Eric Digest, 191, 1-7.

Coetzee, M., \& Roythorne-Jacobs, H. (2012). Career counselling and guidance in the workplace: A manual for career practitioners, 2nd edition. Cape Town, South Africa: Juta.

D’Manto, A., \& Herzfeldt. R. (2008). Learning orientation, organizational commitment and talent retention across generations: A study of European managers. Journal of Managerial Psychology, 23(8), 929-953.

Döckel, A. (2003). The effect of retention factors on organisational commitment: An investigation of high technology employees. Unpublished MCom dissertation (Human Resources Management), University of Pretoria.

Döckel, A., Basson, J.S., \& Coetzee, M. (2006). The effect of retention factors on organisational commitment: An investigation of high technology employees. SA Journal of Human Resource Management, 4(2), 20-28.

Fallic, B., Fleischman, C.A., \& Rebitzer, J.B. (2006). Jobhopping in silicon valley: Some evidence concerning the microfoundations of a high-technology cluster. The Review of Economics and Statistics, 88(3), 472-481.

Feldman, D., \& Ng, T. (2007). Careers: Mobility, embeddedness, and success. Journal of Management, 33(3), 350-377.

Foong-ming, T. (2008). Linking career development practices to turnover intention: The mediator of perceived organizational support. Journal of Business and Public Affairs, 2(1), 1-20.
Khatri, N., Fern, C.T., \& Budhwar, P. (2001). Explaining employee turnover in an Asian context. Human Resource Management Journal, 11, 54-74.

Kochanski, J., \& Ledford, G. (2001). 'How to keep me': Retaining technical professionals. Research Technology Management, 44(3), 31-38.

Kondratuk, T.B., Hausdorf, P.A., Korabik, K., \& Rosin, H.M. (2004). Linking career mobility with corporate loyalty: How does job change relate to organizational commitment? Journal of Vocational Behavior, 65, 332-349.

Lesabe, R.A., \& Nkosi, J. (2007). A qualitative exploration of employees' views on organisational commitment. $S A$ Journal of Human Resource Management, 5(1), 35-44.

Levy, P. (2010). Industrial/organizational psychology: Understanding the workplace, 3rd ed. New York: Worth Publishers.

Lo Presti, A. (2009). Snakes and ladders: Stressing the role of meta-competencies for post-modern careers. International Journal for Educational and Vocational Guidance, 9, 125-134.

Lumley, E.J. (2009). Exploring the relationship between career anchors, job satisfaction and organisational commitment (Unpublished master's dissertation). University of South Africa, Pretoria.

Mallol, C.M., Holtom, B.C., \& Lee, T.W. (2007). Job embeddedness in a culturally diverse environment. Journal of Business Psychology, 22, 35-44.

Martin, A. (2007). Employee perceptions of organisational commitment, job satisfaction and turnover intentions in a post-merger institution (Unpublished master's dissertation). University of Johannesburg, Johannesburg.

Martin, A., \&. Roodt, G. (2007). Employee perceptions of organizational commitment, job satisfaction and turnover intentions in a post merger institution. South African Journal of Industrial Psychology, 34(1), 23-31.

Meyer, J.P., \& Allen, N.J. (1991). A three-component conceptualization of organizational commitment. Human Resource Management Review, 1(1), 61-89.

Meyer, J.P., \& Allen, N.J. (1997). Commitment in the workplace: Theory, research and application. London: Sage Publications.

Meyer, J.P., \& Herscovitch, L. (2001). Commitment in the workplace: Toward a general model. Human Resource Management Review, 11, 299-326.

Mguqulwa, N. (2008). The relationship between organisational commitment and work performance in an agricultural company (Unpublished master's dissertation). University of South Africa, Pretoria.

Mncwango, B., \& Winnaar, L. (2009). South Africans at work: How satisfied are we? HSRC Review, 7(3), 10-11.

Ng, T.W.H., Sorensen, K.L., Eby, L.T., \& Feldman, D.C. (2007). Determinants of job mobility: A theoretical integration and extension. Journal of Occupational and Organizational Psychology, 80, 363-386.

Pato, T., \& Spira, J. (2008). SA searching in vain for 22000 accountants. Retrieved from http://beta.saica.co.za/tabid 
/1185/itemid/903/SA-searching-in-vain-for-22-000accountants.aspx

Rhoades, L., \& Eisenberger, R. (2002). Perceived organizational support: A review of the literature. Journal of Applied Psychology, 87, 698-714.

Robbins, P.R., \& Judge, T.A. (2009). Organizational behaviour. 13th ed. Upper Saddle River, NJ: Pearson.

South African Institute of Chartered Accountants. (2008). The financial management, accounting and auditing skills shortage research report, 2008. Retrieved from https://www.saica.co.za/documents/Skills_Report_sh.pdf

Spector, P.E. (2000). Industrial \& organizational psychology: Research and practice (10th ed.). New York: Wiley \& Sons.
Statistical Package for the Social Sciences. (2008). Statistical Programs for Social Sciences (SPSS): Version 17.0. SPSS Inc.

Sutherland, M., \& Jordaan, W. (2004). Factors affecting the retention of knowledge workers. SA Journal of Human Resource Management, 2(2), 55-64.

Torrington, D., Hall, L., Taylor, S., \& Atkinson, C. (2009). Fundamentals of human resource management. London: Pearson.

Vallabh, M., \& Donald, F. (2001). A comparison of black and white managers on intent to leave and job mobility. Journal of Industrial Psychology, 27(2), 37-42.

Wayne, S., Shore, L., Bommer, W., \& Tetrick, L. (2002). The role of fair treatment and rewards in perceptions of organizational support and leader-member exchange. Journal of Applied Psychology, 87, 590-598. 